\title{
異なる糊を使用した京友禅染の構造と感性評価の関係 \\ - Relationship between Structure and Kansei Evaluation of Kyo-Yuzen-Zome with Different Pastes -
}

O古川貴士（京都工芸繊維大学院）、成田智恵子（京都工芸繊維大学院）

遠藤淳司 (京都工芸繊維大学院)、高井由佳 (大阪産業大学)、後藤彰彦 (大阪産業大学)

Takashi FURUKAWA, Chieko NARITA, Atsushi ENDO (Kyoto Institute of Technology),

Yuka TAKAI, Akihiko GOTO (Osaka Sangyo University)

\section{1.はじめに}

日本において伝統的な着物への染色法は友禅染 と呼ばれており、その中でも京都で染色されたも のは特に“京友禅染”と呼ばれている。京友禅染 は、手描友禅、型友禅、スクリーン捺染、機械捺 染の4 種類に大きく分類される。その中でも代表 的な手描友禅は本友禅、系目友禅、手挿友禅とも 言われ、各工程別に分業化されており、全工程が 手仕事による一品作品を基本としている。

手描友禅の染色工程には大きく10 工程ある。 Fig. 1に工程のフローチャートを示す。第1 工程 「下絵」は、意匠図案にもとづき白生地に青花液 で模様を描く。第2工程「糊置」は、下絵の線に 沿って糸目糊を置き、挿友禅の際に染料が他の部 分ににじまないようにする。Fig. 2に糊置の作業 風景を示し、Fig. 3に糊置の役割の模式図を示す。 第3 工程「糊伏せ」は、模様の部分を糊で伏せる ようにすることで、引染めの際に模様に染料が入 らないようにする。第4 工程「引染め」は、色合 わせをした染料を刷毛で均一に、またはぼかしな がら染める。第5 工程「蒸し」は、引染めされた 生地を蒸し箱に入れ、約 $100^{\circ} \mathrm{C}$ の蒸気で20～50 分 間蒸すことで、生地に地色 (染料) を定着させる。 第6工程「水元」は、完全に染料が定着された生 地を、水で余分な染料や薬剤、糊料をきれいに洗 い流す。第7 工程「挿友禅」は、筆と刷毛を駆使 して絵模様部分に色を挿す。第8 工程「湯のし」 は、生地に蒸気をあててシワを伸ばし、風合いを 柔らかくする。第9 工程「金彩 (金加工)」は、 華やかにするために、染め上がった生地に金・銀 の箔や粉を接着する仕上げを施す。第10 工程 「刺紼」は、ボリューム感を与えることで気品と 豪華さを持たせる。本研究で取り上げた糊置工程 では、主にでんぷん糊とゴム糊を用いる。でんぷ 几糊を用いた場合、仕上がりが全体的に柔らかく 見え、味わい深くなり、見た目にも温かさを得る ことができるとされている。そのためゴム糊より もでんぷん糊を用いた方が、最終的な商品価值が
高い。本研究では、この最終製品評価の差を解明 するために、京友禅染を評価する際に用いられる 「はんなり」といら京都における方言を用いて、 感性評価アンケートを行った。さらに、でんぷん 糊とゴム糊を用いて作製した製品の表面・断面を 観察することで、繊維へのでんぷん糊およびゴム 糊の浸透性を評価しアンケート結果との相関を明 らかにした。

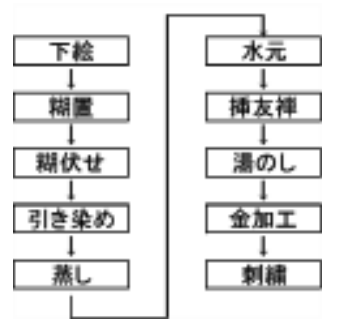

Fig. 1 Flowchart of manufacturing process.

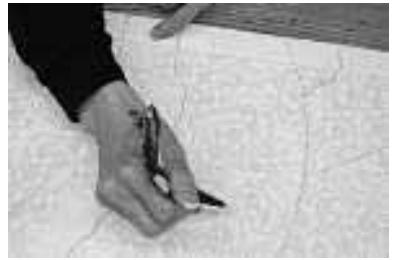

Fig. 2 Picture of putting paste.

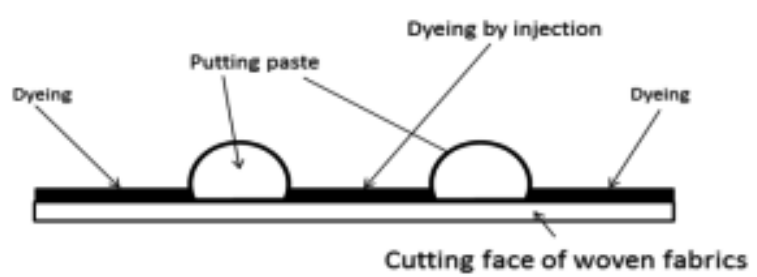

Fig. 3 shows cutting face of woven fabrics.

\section{2. 方法}

2.1. 感性評価アンケート

2.1.1. サンプル アンケートで用いたサンプ ルをFig. 4に示す。でんぷん糊を用いて染め上げ た染帯A、ゴム糊を用いて染め上げた染帯B の2 種類を用意した。サンプルの作製は、経験年数約 50 年の糊置職人（70 歳、男性、右利き）が行っ た。生地は正絹であり、比較検討を行うため同じ 図柄とした。 
2.1.2. アンケート対象者 染織業界に長く携 わっている方から業界歴が全くない方まで、京友 禅染の製造者、職人、販売者、消費者100名を対 象に行った。

2.1.3. アンケート方法 アンケートでは、ま ず染帯A、染帯B について、はんなり度合いを5段 階で評価させた。次に、染帯A、染帯Bについて、 はんなり以外の要素を検討するため、シャープさ、 上品さ、明るさ、温かさ、豊かさ、深みを5段階 にて評価させた。

\section{2. 表面観察および断面観察}

2.2.1. 表面観察 でんぷん糊・ゴム糊を用 いて作製した製品(素材 : 正絹)の表面観察を、倒 立型金属顕微鏡(PME3:オリンパス株式会社製)を 用いて行った。

2.2.2. 断面観察 でんぷん糊・ゴム糊を用い て作製した製品(素材: 正絹)を緯糸に沿って切断 し、包埋して研磨した試験片を準備し、倒立型金 属顕微鏡(PME3:オリンパス株式会社製)を用いて 行った。

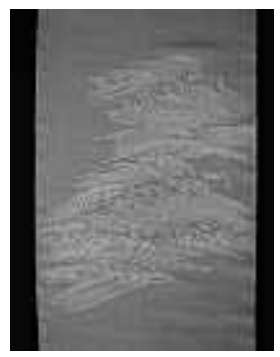

Sample (A)

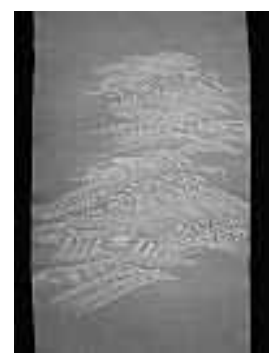

Sample (B)
Fig. 4 Sample (A) dyeing with starch paste and Sample (B) dyeing with rubber paste.

\section{3. 結果と考察}

3.1. アンケート結果 Fig.5にでんぷん糊と ゴム糊の評価点および各要素の平均評価点を示す。 でんぷん糊は上品さ、温かさ、豊かさ、深みにつ いてゴム糊より高い評価点を示し、ゴム糊は シャープさについてでんぷん糊より高い評価点を 得る結果となった。明るさに関してはでんぷん糊、 ゴム糊ともに近い評価点を示した。はんなり度合 いについては、でんぷん糊の方が、ゴム糊よりも 高い評価点を得られたことから、きものに求めら れるはんなり度合いは、でんぷん糊を使用した製 品の方が高いことが明らかとなった。

3.2. 表面観察の結果 Fig. 6にでんぷん糊、 およびゴム糊の表面画像を示す。画像黒色部分は 染色されており、白色部分はでんぷん糊およびゴ
ム糊のために染色されていない。ゴム糊と比較し てでんぷん糊を用いて作製された製品は、染色さ れた部分と染色されていない部分の境界がはっき りしていないことがわかった。このことがでんぷ ん糊のはんなり度合いを高めていると考えられる。

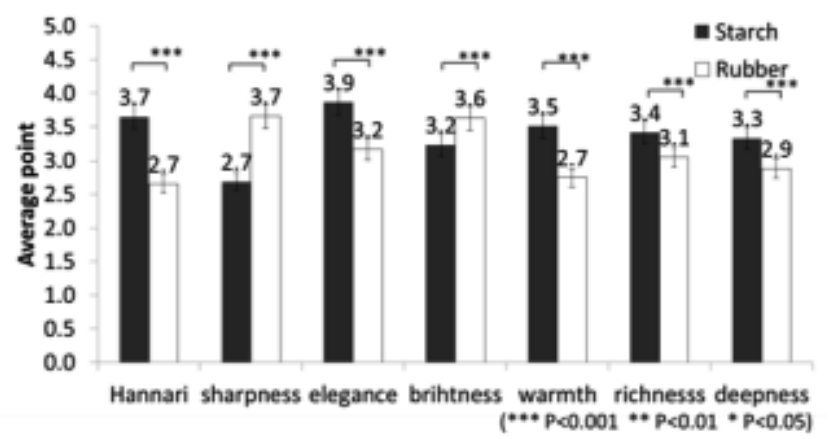

Fig. 5 Average point of each question.
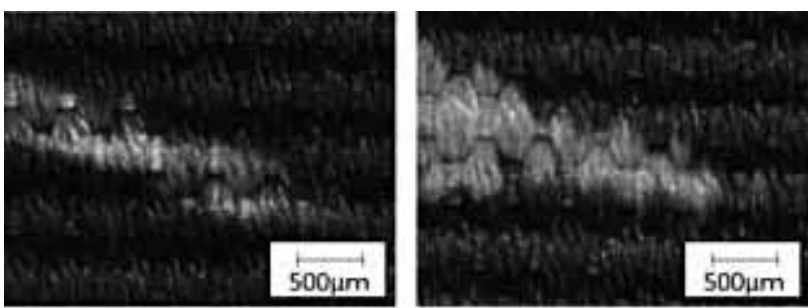

Fig. 6 Surface of starch and rubber.

3.3. 断面観察の結果 Fig. 7 亿でんぷん糊お よびゴム糊で糊置きされた断面画像を示す。ゴム 糊はでんぷん糊よりも䋊維束への接着面積が大き く浸透しており、このことが染色された部分と染 色された部分の境界がはっきり仕上がる原因では ないかと考えられる。
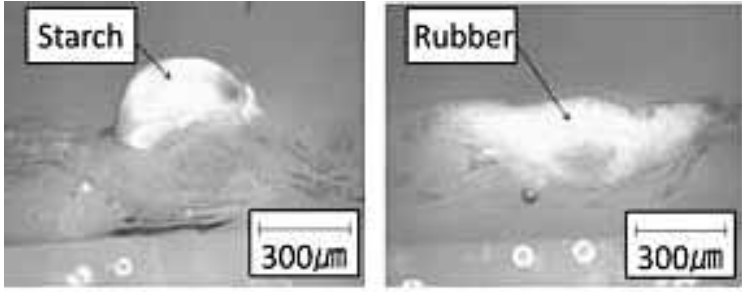

Fig. 7 Cutting face of fabrics.

4. まとめ

アンケートから、京友禅染においてはでんぷん 糊を使用した場合に「はんなり度合い」が高まる ことが明らかとなった。この要因のひとつとして、 染色部分と未染色部分の境界に差異があることが 表面観察より明らかになり、䋊維束への浸透度の 差異が断面観察より明らかになった。今後、糊置 き職人の動作解析を行って、異なる材料が動作に 及ぼす影響と染色部分との関係について研究する 必要があると考えられる。 